\title{
Tissue Specific Metal Contamination and Consumption Risk Characterisation of Three Marine Fish Species of Visakhapatnam Coast
}

\section{Srinivasulu A ${ }^{1}$, A Jayasree ${ }^{1}$, GVV Satyanarayana ${ }^{1}$, Daisy Joseph ${ }^{3 *}$, PVL Narayana ${ }^{1}$, P Yedukondala Rao ${ }^{2}$ and ADP Rao ${ }^{1}$}

${ }^{1}$ Department of Nuclear Physics, Andhra University, Visakhapatnam, India

${ }^{2}$ Department of Marine Living Resources, Andhra University, Visakhapatnam, India

${ }^{3}$ Nuclear Physics Division, Bhabha Atomic Research Centre, Mumbai, India

*Corresponding Author: Daisy Joseph, Nuclear Physics Division, Bhabha Atomic

Research Centre, Mumbai, India.
Received: August 03, 2021

Published: September 14, 2021

(C) All rights are reserved by Daisy Joseph., et al.

\begin{abstract}
Concentration of various metals, i.e., Arsenic (As), Copper (Cu), Manganese (Mn), Cadmium (Cd), Iron (Fe), Zinc (Zn) and Selenium (Se) is determined in commonly consumed three marine fish species namely Scomberomorus lineolatus, Lutjanus johni and Arius jella using Hand-held X-ray Ray Fluorescence (HHXRF). From this study, it is observed that, overall, Arius jella found to accumulate higher amounts of all the elements except Fe, whereas Scomberomorus lineolatus exhibited higher concentration of Fe. Further, there is a tissue-specific discrimination among the fish species selected for the present study. Fish liver contains higher metal concentrations followed by gills, and finally the least contents in fish muscle. It is also observed that there is variation among the fish species in addition to the variation of metal concentration among the tissues. The estimated daily intake and hazard quotient are evaluated for all the elements. The hazard quotient for As and $\mathrm{Cd}$ are greater indicating that the fishes belonging to this particular area seem to be not safe for human consumption.
\end{abstract}

Keywords: Marine Fish; Heavy Metal; HHXRF; Consumption Risk; Scomberomorus lineolatus; Lutjanus johni; Arius jella

\section{Introduction}

The nutritional and health benefits of bioactive compounds derived from seafood are well-known established facts. Marine fish provides essential nourishment, especially omega-3 polyunsaturated fatty acids (PUFAs), Protein, Iodine, Selenium, Taurine and Vitamin D which are essential for Human health and nourishment. The consumption of fish helps in preventing coronary heart disease (CHD) is also useful for the brain activity. It is also useful source of information to the general public. Even moderate or low consumption of fish has significant effect on CHD prevention [1]. There is a consistent evidence that cardiovascular disease risk is decreased with the intake of oily fish [2] and the fish consumption is related to reduced risk of stroke [3]. The recent studies showed that the consumption of oily fish led to improvement in reduction of Triglycerides and High-Density Lipoprotein (HDL) levels which are import biomarkers of cardiovascular risk.

Some of the recent studies suggested that the consumption of fish may reduce the incidence of total gastrointestinal cancer [4] 
and has a potential role in the prevention of liver cancer [5] and oesophageal cancer [6]. Recent studies showed that consumption of fish is inversely related with colorectal cancer [7] and suggests that high consumption of some fish is significantly related to a decreased risk of lung cancer [8]. The risk of multiple myeloma is also inversely associated with the fish consumption [9].

The PUFAs derived from marine fish consists of Eicosapentaenoic acid (EPA), Docosahexaenoic acid (DHA) and Docosapentaenoic acid (DPA) $[10,11]$. The eicosapentaenoate extracted from fish oil has antithrombotic effect [12]. EPA and DHA improves the inflammation status in hypercholesterolemic adults [13]. The supplementation of the maternal diet with EPA can decrease placental lipid deposition and improve antioxidant ability [14]. EPA reduces adiposity, glucose intolerance and increases oxygen consumption [15]. The data of a recent study suggests that EPA exhibits better effects on ameliorating memory and cognitive function [16].

However, there is increasing attention for the presence of contaminants in aquatic environments and heavy metals accumulation in some fish species. Marine environment is being monitored globally on a regular basis for heavy metal contamination and the application of biomarkers for providing the evidence for the exposure of coastal areas to the chemical contaminants is being increased. The response of biomarkers at cellular and molecular levels gives the earliest warning signals of environmental pollution. So, it was stated that the use of fish biomarkers is necessary to monitor marine environment and to evaluate the impact of heavy metals on fish [7,17]. Some elements like $\mathrm{Zn}, \mathrm{Co}, \mathrm{Ni}, \mathrm{Fe}, \mathrm{Cu}$ and $\mathrm{Mn}$ are important and essential for healthy cell function when present at low concentrations and become toxic when accumulated at high concentrations. Some of the metals such as $\mathrm{Pb}, \mathrm{Hg}, \mathrm{Cd}$ and $\mathrm{Ag}$ are toxic even present at low concentrations for living organisms [18].

The metal accumulation in fish is affected by many factors such as feeding strategy, trophic status, gender and phase of sexual reproduction, age and size of the fish, and the local marine environment. The results of a study from Kuwait Bay and the northern area of Kuwait showed the variation in the concentration of total and methyl mercury (MeHg) in different fish species and there is a relationship between the observed concentration, feeding habits and habitat. The mercury concentration is also correlated with weight and length of the species analysed [19]. A study conducted in Persian Gulf revealed the influence of seasonal variation in the concentration of the metals in the fish samples [20]. It could be observed an exponential correlation in which the mercury concentration increases with an increase in fish length or age from some investigations [21]. It is observed from a research work carried out on Lethrinus lentjan that liver, muscle and skin of female fish accumulated higher levels of average metal concentrations than those found in the male fish [22]. The metal content in both Pampus argenteus and Otolithes ruber varied with type of metals, sex and organ in a recent investigation [23]. A study conducted on edible muscle of fish samples revealed that the concentration of As and $\mathrm{Hg}$ is influenced by seasonal variation [20]. The site differences in mean concentrations of $\mathrm{Pb}, \mathrm{Hg}$ and $\mathrm{Cd}$ in the flesh and liver of 338 roach and 885 eel fishes collected from different sites on the Rivers Brett and Chelmer, eastern England was also recorded [24].

Visakhapatnam is one of the major port cities of India, having a variety of industries ranging from steel, engineering, ship building yard, chemicals, fertilizers, petroleum besides a thermal power plant. Fishing is a major occupation in the city, as many fishermen depend on fishing for their livelihood. In recent years, the pollution problems are aggravated in sea coast as a result of multiple industrial discharges and local untreated sewage indicating a serious threat to the safety of fish as well as for the consumers. Realising the nutritional and health benefits of marine fish to population and worrying about the ever-growing pollution of Visakhapatnam seacoast, it is proposed to estimate heavy metals ( $\mathrm{As}, \mathrm{Cd}, \mathrm{Cu}, \mathrm{Fe}, \mathrm{Mn}$, $\mathrm{Se}, \mathrm{Zn}$ ) concentration in different organs (Muscle, liver and gills) of three marine fishes namely Scomberomorus lineolatus, Lutjanus johni and Arius jella as they are commonly consumed fish species and best suited to evaluate the heavy metal pollution in this area.

\section{Sample collection and preparation}

For the present study, three coastal water fishes commonly consumed in the region (Scomberomorus lineolatus $(40-44 \mathrm{~cm}, \mathrm{TL})$, Lutjanus johni (28-31cm, TL) and Arius jella (30-32cm, TL)) were collected freshly from Visakhapatnam fishing harbour (Geographical coordinates $17.6958^{\circ} \mathrm{N}, 83.3025^{\circ} \mathrm{E}$ ). The sample collection area near Visakhapatnam coast is shown in figure 1. The marine fishes collected are shown in fig. 2 . The fishes are packed in sterile polythene bags with separate identification and transported to the laboratory in an ice cooled box. Three samples of each species were collected at different dates from November to January 2020. 


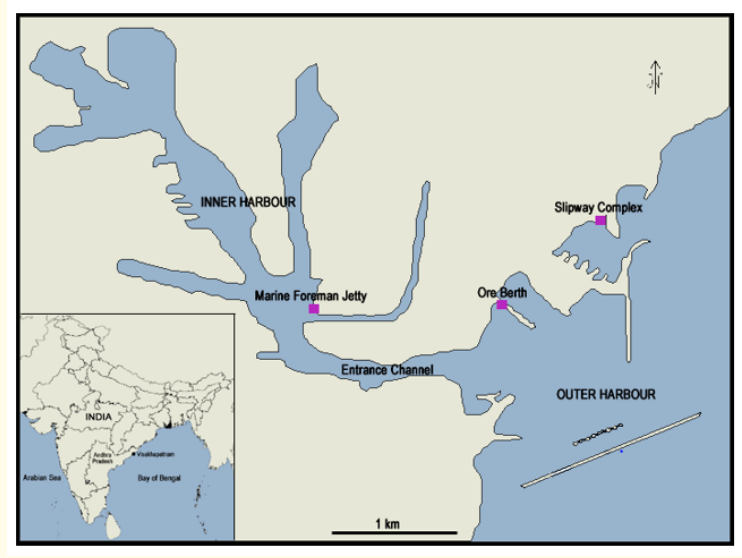

Figure 1: Sampling area in Visakhapatnam fishing harbour.

The fishes were cleaned with sterile distilled water and carefully dissected for the collection of vital parts (muscle, liver and gills) of each fish is to be taken as a sample. Then the fish samples were kept in laboratory deep freezer at $-20^{\circ} \mathrm{C}$ for overnight. Frozen samples were then lyophilized with microprocessor-controlled freeze method. The freeze-drying work at $-50^{\circ} \mathrm{C}$ that absorbs the water molecules of the samples drains out of the system making the samples dry. The dried fish samples are ground using Mortar-Pestle as a fine powder minimising the probability of contamination and keep each of the sample powder separately with its ID number in the airtight packet.

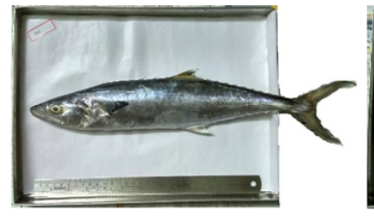

(a)

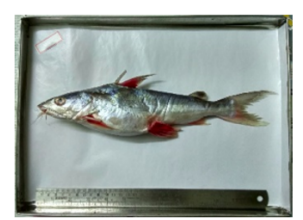

(c)

Figure 2: The fish samples collected from Visakhapatnam fishing harbour.

\section{Experimental method}

The experiment was performed at Nuclear Physics Division, BARC, Mumbai by Hand-held XRF. In a typical XRF spectrometer, the sample is excited with X-rays coming out of an X-ray tube with sufficient energy to eject the electrons from different inner shells of the atoms of the sample. Then, the vacant inner shell positions are filled by the electrons from outer shells and as a result the emission of characteristic X-rays takes place. It was known as conventional X-ray fluorescence (XRF). However, a Silicon Drift Detector (SDD) is employed in Hand-held XRF to measure the X-ray energies of the emitted X-rays. The Silicon Drift Detector (SDD) is provided with a graphene window for enabling low $\mathrm{Z}$ elements ( $\mathrm{Al}, \mathrm{P}$ and $\mathrm{S}$ ) detection. These elements are generally not detected by using conventional XRF in which a Be window is used. The finely powdered sample was irradiated by X-ray tube (Rhodium tube) in a cubical box. The spectrum of each was obtained within 20 seconds. The beam lines used were of (Beam 1 from 12 to $36 \mathrm{keV}$ ) and Beam 2 from 0-12 KeV) [25]. The HHXRF set up was shown in figure 3.

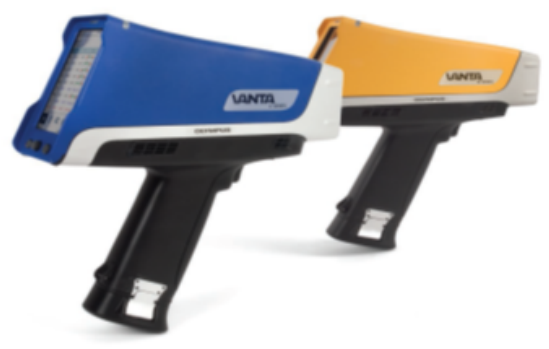

Figure 3: HHXRF set up.

\section{Results and Discussion}

The concentrations of heavy metals such as $\mathrm{Fe}, \mathrm{Zn}, \mathrm{Cu}, \mathrm{As}, \mathrm{Mn}$, $\mathrm{Cd}$ and Se accumulated in different organs (muscle, liver and gills) of fish collected from Visakhapatnam fishing harbour on the Bay of Bengal are given in tables 1, 2 and 3 respectively. The accumulation of elements is significantly different among different species and organs. Muscle contained the lowest concentrations of elements except for As in all fish, while the highest accumulation of $\mathrm{Cu}, \mathrm{Fe}$, 
Se and $\mathrm{Zn}$ found in the liver in almost all the fish and gills show the highest concentrations of Mn. The highest concentrations of Cd are fluctuated between the muscle in some species and liver in others. However, different patterns of metal accumulation were observed in different organs and not a single fish species observed to have highest accumulation of elements in all organs. Therefore, the elemental concentrations among the species were analysed in single organ. The results showed a discrimination among the fish species chosen. The XRF spectra of nine samples (i.e., muscle, liver and gills of Scomberomorus lineolatus, Lutjanus johni and Arius jella) recorded while doing the experiment were shown in Fig. 4. The ranges of daily dietary intake (DDI) of all the elements are calculated compared with recommended dietary allowances in table 4 . The estimated daily intake (EDI) and hazard quotient are calculated and shown in table 5 .

\section{Arsenic (As)}

'As' enters into marine environment through various sources such as smelting operations, mineral or strip mines, and power plants. One of the agricultural sources for As contamination in the environment is the manufacturing, use of pesticides and arsenical defoliants. It also has been used to kill aquatic plants to reduce the difficulty encountered during hook-and-line fishing of areas overgrown with aquatic vegetation. In aquatic organisms, 'As' may accumulate with higher quantities in reservoirs and on the sediments of water courses [26]. As (III) (arsenites) is more toxic than As (V) (arsenates) and rapidly absorbed in fish [27].

The highest concentration of As reported in the muscle tissue of Arius jella. In Scomberomorus lineolatus, As accumulation found to be more in liver $(40.0 \pm 17.3 \mathrm{ppm})$ followed by muscle $(7.0 \pm 5.0$ ppm) and gills ( $6.0 \pm 5.0 \mathrm{ppm})$. In Lutjanus johni, the highest concentration of As is observed to be in liver (31.5 $\pm 26.2 \mathrm{ppm})$, further indicated next levels of concentration obtained in muscle (22.0 \pm $5.0 \mathrm{ppm})$ and gills $(7.4 \pm 3.2)$. In Arius jella, muscle (95.7 \pm 72.3 ) exhibited highest concentration of As while lowest concentration seems to occur in gills $(8.0 \pm 6.0)$. The Daily dietary intake (DDI) of As ranges from 54.6 to $746 \mu \mathrm{g} /$ day, recommended daily allowance is $130 \mu \mathrm{g} /$ day, estimated daily intake ranges from 0.78 to $10.66 \mu \mathrm{g}$ $\mathrm{kg} \mathrm{BW}^{-1}$ day $^{-1}$, Hazard quotient ranges from 2.6 to 35.54 .

\section{Cadmium (Cd)}

Cd is a trace metal, found naturally in the earth's crust which is nonessential for living organisms. It can bioaccumulate often at hazardous levels and increases its' environmental concern [2830]. During $20^{\text {th }}$ century, the production and emission of $\mathrm{Cd}$ to the environment was increased rapidly by using it in batteries, plastic stabilizers, electroplating, pigment and consequently cause contamination of marine organisms [31]. The Cd contamination of soil and water is mainly due to manufacturing and usage of phosphate fertilizers, mining and refining of non-ferrous metals, combustion of fossil fuel and waste disposal. Cd is able to accumulate in agricultural crops and marine organisms [32].

The highest concentration of $\mathrm{Cd}$ reported in the liver tissue of Lutjanus johni. In Scomberomorus lineolatus, the Cd concentration is in a narrow range, liver accumulated highest concentration (25.0 $\pm 21.0 \mathrm{ppm}$ ) and gills found to receive lowest concentration (18.6 $\pm 2.6 \mathrm{ppm}$ ). In the case of Lutjanus johni fish the obtained concentration of $\mathrm{Cd}$ in the decreasing order reflected as liver (32.5 \pm 0.7$)$, muscle $(21.0 \pm 1.4)$ and gills $(20.0 \pm 1.2)$. Arius jella is also exhibited $\mathrm{Cd}$ concentration only in a narrow range from $23.0 \pm 2.8$ (gills) to $31.5 \pm 2.1$ (muscle). The Daily dietary intake (DDI) of Cd ranges from 163.8 to $245.7 \mu \mathrm{g} /$ day, estimated daily intake ranges from 2.34 to $3.51 \mu \mathrm{g} \mathrm{kg} \mathrm{BW}^{-1}$ day $^{-1}$, Hazard quotient is ranges from 2.34 to 3.51 .

\section{Copper (Cu)}

$\mathrm{Cu}$ is an essential trace element (micronutrient) for living organisms; it is one of the key constituents of metabolic enzymes [33]. When accumulated in higher concentrations in marine species, $\mathrm{Cu}$ can become extremely toxic for their intracellular mechanisms $[34,35]$. It enters into the environment through natural and anthropogenic sources. The $\mathrm{Cu}$ contamination of water is contributed from mining, refining and concentrating copper ores, petroleum, iron and steel and fertilizer industries [36]. The accumulation of $\mathrm{Cu}$ in fish is through diet and ambient exposure [28]. Even present at low concentrations in the environment, $\mathrm{Cu}$ shows high affinity to be accumulated by fish liver [37].

The highest concentration of $\mathrm{Cu}$ reported in the liver tissue of Arius jella. Scomberomorus lineolatus fish accumulated $\mathrm{Cu}$ concentration found to vary in between $17.6 \pm 1.8 \mathrm{ppm}$ (Muscle) to $22.3 \pm$ 9.5 ppm (Liver). In Lutjanus johni, $\mathrm{Cu}$ concentration is observed to be highest in liver $(40.7 \pm 24.1 \mathrm{ppm})$ and lowest presence in muscle $(19.4 \pm 2.6 \mathrm{ppm})$. Liver $(44.5 \pm 33.2 \mathrm{ppm})$ is the highest $\mathrm{Cu}$ accumulated organ while muscle $(22.8 \pm 2.6 \mathrm{ppm})$ shows the lowest

Citation: Daisy Joseph., et al. "Tissue Specific Metal Contamination and Consumption Risk Characterisation of Three Marine Fish Species of Visakhapatnam Coast". Acta Scientific Pharmaceutical Sciences 5.10 (2021): 29-39. 
$\mathrm{Cu}$ accumulated organ in Arius jella fish. The Daily dietary intake (DDI) of Cu ranges from 137.28 to $177.84 \mu \mathrm{g}$ /day, recommend daily allowance is $3,000-30,000 \mu \mathrm{g} /$ day, estimated daily intake ranges from 1.96 to $2.54 \mu \mathrm{g} \mathrm{kg} \mathrm{BW}{ }^{-1} \mathrm{day}^{-1}$, Hazard quotient is ranges from 0.04 to 0.06 .

Iron (Fe)

Fe generally enters the marine environment through mining and industrial effluents. In fish, Ferric iron (Fe3+) was considered to be less toxic than the ferrous (Fe2+) form [38]. The Fe is likely to be accumulated in higher concentration in liver and gonads of fish [39]. In a recent study, it was proved that liver is the target organ for Fe in fish [40]. Respiratory disruption due to physical clogging of the gills is suggested as a possible mechanism for Fe toxicity [41].

The highest concentration of Fe reported in liver tissue of Scomberomorus lineolatus. In Scomberomorus lineolatus, a large variation is observed in the concentration of Fe ranging from $29.0 \pm 9.5 \mathrm{ppm}$ (muscle) to $6946.7 \pm 3904.6 \mathrm{ppm}$ (liver). In Lutjanus johni, Fe found to be more in liver (2720.0 $\pm 670.9 \mathrm{ppm})$ while lower contents in muscle (28.5 $\pm 4.9 \mathrm{ppm})$. In Arius jella also, the concentration of Fe followed the same order as in the other species, ranging from $2857.3 \pm 1661.0 \mathrm{ppm}$ (liver) to $41.0 \pm 17.1 \mathrm{ppm}$ (muscle). The Daily dietary intake (DDI) of Fe is 222.3 to $319.8 \mu \mathrm{g} /$ day, recommended daily allowance is $19,000 \mu \mathrm{g}$ /day, estimated daily intake is 3.17 to $4.56 \mu \mathrm{g} \mathrm{kg} \mathrm{BW}^{-1} \mathrm{day}^{-1}$, Hazard quotient is 0.004 to 0.006 .

\section{Manganese (Mn)}

The anthropogenic source of Mn is its' emission from ore mining, production of Mn alloys, welding, battery manufacturing, coke ovens and Mn salt production. It has widespread use in manufacturing of glass, ceramics, electronic components and aluminium cans. Manganese-containing agrochemicals like fertilizers and fungicides are extensively used in some countries. Sewage sludge and discharges of waste water in urban areas are also considerable sources of Mn.

The highest concentration of Mn reported in gill tissue of Arius jella. Accumulation of $\mathrm{Mn}$ in Scomberomorus lineolatus fish ranges from $35.0 \pm 27.0 \mathrm{ppm}$ (muscle) to $66.7 \pm 37.3 \mathrm{ppm}$ (gills) in the present studies. Lutjanus johni exhibited concentration of $\mathrm{Mn}$ in liver $(46.0 \pm 11.3 \mathrm{ppm})$ and gills $(46.5 \pm 0.7 \mathrm{ppm})$ seems to be nearly equal levels and relative to these values muscle (29.0 \pm 23.0$)$ showed lesser concentration. In Arius jella, the highest concentration of $\mathrm{Mn}$ is presented in gills ( $94.3 \pm 42.0 \mathrm{ppm}$ ) having presence of lowest concentration in $(25.0 \pm 24.0 \mathrm{ppm})$. The Daily dietary intake (DDI) of Mn is 195 to $273 \mu \mathrm{g} /$ day, estimated daily intake is 2.78 to $3.9 \mu \mathrm{g} \mathrm{kg} \mathrm{BW}^{-1}$ day $^{-1}$, Hazard quotient is 0.019 to 0.027 .

Selenium (Se)

Se is a trace element essential for physiological function and normal growth of living organisms, including fish $[42,43]$. It is important for normal development, maintenance and growth of homeostatic functions [44]. Se involves in antioxidant defence system and plays a role in metabolism of thyroid hormone and in spermatogenesis [45]. it is also involved in various functions such as cancer prevention and moderation of immune system, acting as the support to organismal health [46]. Sewage sludge, drain water from agricultural lands, fly ash coming out of thermal power plants, mining of metal ores and phosphates and oil refineries are some of the sources of Se contamination in the marine environment $[47,48]$.

The highest accumulation of Se is observed in the liver tissue of Arius jella. In the present investigation, Se is detected in a very narrow range among all the organs of species. In Scomberomorus lineolatus, Se accumulated value in liver observed to be7.7 \pm 3.5 ppm while it exhibited $6.3 \pm 2.3$ ppm in gills and muscle showed 5.2 $\pm 1.2 \mathrm{ppm}$. In Lutjanus johni, gills $(3.0 \pm 0.7)$ found to contain lowest concentration and liver $(4.0 \pm 1.4)$ indicated highest concentration of Se. In Arius jella, Se found to be more in liver (11.5 $\pm 7.8 \mathrm{ppm})$ and less in gills $(7.3 \pm 4.0)$. The Daily dietary intake (DDI) of Se is 24.96 to $74.88 \mu \mathrm{g} /$ day, recommended daily allowance is $110 \mu \mathrm{g} /$ day, estimated daily intake is 0.35 to $1.06 \mu \mathrm{g} \mathrm{kg} \mathrm{BW}^{-1}$ day $^{-1}$, Hazard quotient is 0.071 to 0.21 .

\section{Zinc (Zn)}

After $\mathrm{Fe}, \mathrm{Zn}$ is the most abundant trace element and essential micronutrient for living organisms. It is found almost in every cell and involves in synthesis of nucleic acids and many enzymes [28]. Additionally, $\mathrm{Zn}$ associate in complicated functions like immune system, cell signalling and neurotransmission [49]. In water, Zn occurs as free cation like soluble zinc complexes and it is adsorbed on suspended matter. $\mathrm{Zn}$ and its compounds are widely used in medicine. The major sources of $\mathrm{Zn}$ accumulations may be due to galvanized iron work, $\mathrm{Zn}$ containing paints and zinc chloride utilized in plumbing [50]. Zinc wastes can have a direct toxicity to fish 
at increased waterborne levels [51]. Fish kidney is the major target of Zn toxicity in fish [40].

The highest concentration of Zn reported in liver tissue of Arius jella. In Scomberomorus lineolatus, $\mathrm{Zn}$ is found to be high in liver $(247.0 \pm 41.1 \mathrm{ppm})$ and less in muscle $(41.7 \pm 4.2 \mathrm{ppm})$. Lutjanus johni exhibited concentration of $\mathrm{Zn}$ is from $84.3 \pm 5.7 \mathrm{ppm}$ (gills) to $271.0 \pm 64.5 \mathrm{ppm}$ (liver). Large variation in the concentration of Arius jella fish accumulated $\mathrm{Zn}$ is observed having values from 50.0 $\pm 5.3 \mathrm{ppm}$ (muscle) to $1028.3 \pm 540.4 \mathrm{ppm}$ (liver). The Daily dietary intake (DDI) of $\mathrm{Zn}$ is 249.6 - $390 \mu \mathrm{g} /$ day, recommended daily allowance is $18,000-60,000 \mu \mathrm{g} /$ day, estimated daily intake is 3.56 to $5.57 \mu \mathrm{g} \mathrm{kg} \mathrm{BW}^{-1} \mathrm{day}^{-1}$, Hazard quotient is 0.011 to 0.018 .

\begin{tabular}{|l|c|c|c|}
\hline Metal & Muscle & Liver & Gills \\
\hline $\mathrm{As}$ & $7.0 \pm 5.0$ & $40.0 \pm 17.3$ & $6.0 \pm 5.0$ \\
\hline $\mathrm{Cd}$ & $23.0 \pm 3.6$ & $25.0 \pm 21.0$ & $18.6 \pm 2.6$ \\
\hline $\mathrm{Cu}$ & $17.6 \pm 1.8$ & $22.3 \pm 9.5$ & $19.4 \pm 1.6$ \\
\hline $\mathrm{Fe}$ & $29.0 \pm 9.5$ & $6946.7 \pm 3904.6$ & $721.7 \pm 61.7$ \\
\hline $\mathrm{Mn}$ & $35.0 \pm 27.0$ & $58.7 \pm 31.8$ & $66.7 \pm 37.3$ \\
\hline $\mathrm{Se}$ & $5.2 \pm 1.2$ & $7.7 \pm 3.5$ & $6.3 \pm 2.3$ \\
\hline $\mathrm{Zn}$ & $41.7 \pm 4.2$ & $247.0 \pm 41.1$ & $134.3 \pm 13.0$ \\
\hline
\end{tabular}

Table 1: Evaluation of heavy metals (ppm) concentration in different tissues of Scomberomorus lineolatus.

\begin{tabular}{|l|c|c|c|}
\hline Metals & Muscle & Liver & Gills \\
\hline As & $22.0 \pm 5.0$ & $31.5 \pm 26.2$ & $7.4 \pm 3.2$ \\
\hline $\mathrm{Cd}$ & $21.0 \pm 1.4$ & $32.5 \pm 0.7$ & $20.0 \pm 1.2$ \\
\hline $\mathrm{Cu}$ & $19.4 \pm 2.6$ & $40.7 \pm 24.1$ & $22.8 \pm 2.2$ \\
\hline $\mathrm{Fe}$ & $28.5 \pm 4.9$ & $2720.0 \pm 670.9$ & $350.0 \pm 203.5$ \\
\hline $\mathrm{Mn}$ & $29.0 \pm 23.0$ & $46.0 \pm 11.3$ & $46.5 \pm 0.7$ \\
\hline $\mathrm{Se}$ & $3.2 \pm 1.2$ & $4.0 \pm 1.4$ & $3.0 \pm 0.7$ \\
\hline $\mathrm{Zn}$ & $32.0 \pm 6.6$ & $271.0 \pm 64.5$ & $84.3 \pm 5.7$ \\
\hline
\end{tabular}

Table 2: Evaluation of heavy metals (ppm) concentration in different tissues of Lutjanus johni.

Human health risk assessment

The daily dietary intake (DDI) of each analysed element through fish consumption is related to the daily consumption of fish per

\begin{tabular}{|l|c|c|c|}
\hline Metals & Muscle & Liver & Gills \\
\hline As & $95.7 \pm 72.3$ & $34.5 \pm 24.7$ & $8.0 \pm 6.0$ \\
\hline $\mathrm{Cd}$ & $31.5 \pm 2.1$ & $27.0 \pm 5.7$ & $23.0 \pm 2.8$ \\
\hline $\mathrm{Cu}$ & $22.8 \pm 2.6$ & $44.5 \pm 33.2$ & $32.8 \pm 3.6$ \\
\hline $\mathrm{Fe}$ & $41.0 \pm 17.1$ & $2857.3 \pm 1661.0$ & $1152.0 \pm 906.3$ \\
\hline $\mathrm{Mn}$ & $25.0 \pm 24.0$ & $64.5 \pm 24.7$ & $94.3 \pm 42.0$ \\
\hline $\mathrm{Se}$ & $9.6 \pm 3.6$ & $11.5 \pm 7.8$ & $7.3 \pm 4.0$ \\
\hline $\mathrm{Zn}$ & $50.0 \pm 5.3$ & $1028.3 \pm 540.4$ & $683.0 \pm 452.3$ \\
\hline
\end{tabular}

Table 3: Evaluation of heavy metals (ppm) concentration in different tissues of Arius jella.
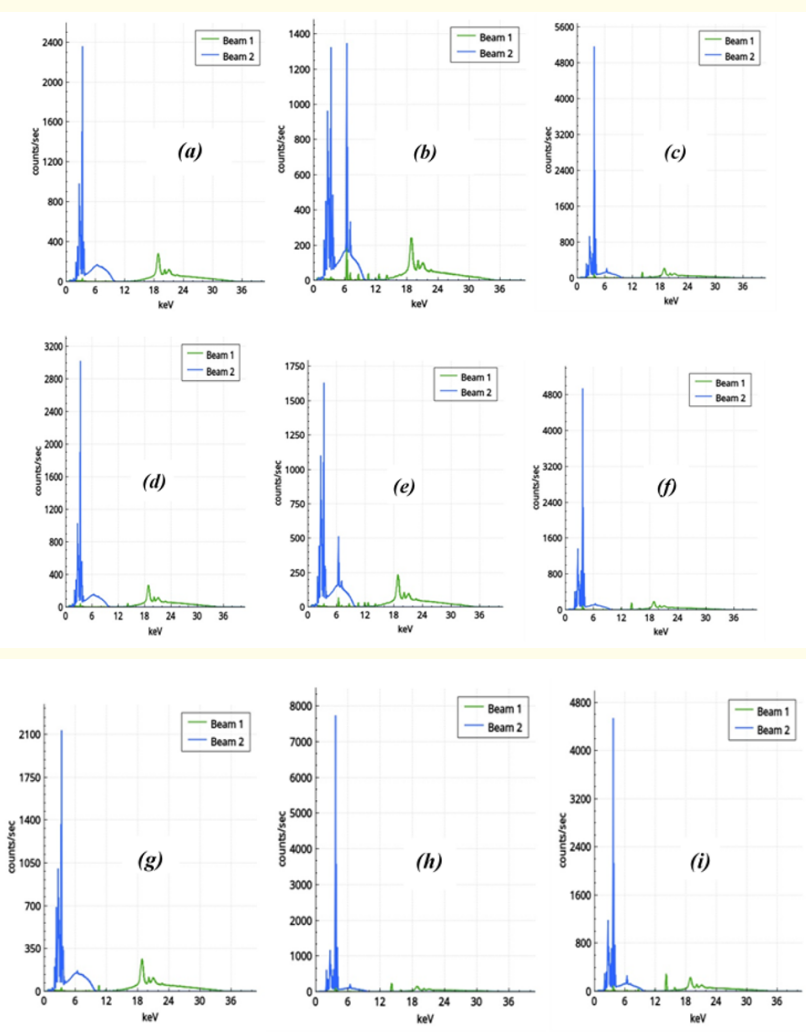

Figure 4: XRF spectra of Scomberomorus lineolatus (a,b,c), Lutjanus johni (d,e,f) and Arius jella (g,h,i).

capita and the elemental concentration in fish. The DDI of the elements for the local population are calculated by using the formula that mentioned below: 
$D D I=C_{f i s h} \times I_{\text {fish }}$

Where, $\mathrm{C}_{\text {fish }}=$ mean metal concentration in fish muscle $(\mu \mathrm{g} / \mathrm{g}$ $\mathrm{ww}$ ), $\mathrm{I}_{\text {fish }}=$ daily fish consumption ( $\mathrm{g} /$ day) per capita. The average consumption of fish and fish products in India is $2.85 \mathrm{~kg}$ per capita per year [52]. Therefore, the daily consumption of fish per capita is calculated as of $7.8 \mathrm{~g}$ for the local population.

The human health risk assessment is based on the calculation of reference dose (RfD) established [53], Estimated Daily Intake and the Hazard Quotient (HQ). The EDI ( $\mu \mathrm{g} \mathrm{kg}^{-1} \mathrm{BW}$ day ${ }^{-1}$ ) was calculated by using the following equation [54]:

$E D I=\frac{C_{f i s h} \times I_{\text {fish }}}{B W}$

Where, BW = average body weight of Indian population taken as $70 \mathrm{~kg}$. The hazard quotient is calculated by using the formula [54]:

$H Q=\frac{E D I}{R f D}$

If HQ is less than 1, there is no risk due consumption of fish.

\begin{tabular}{|l|c|c|}
\hline \multicolumn{1}{|c|}{ Elements } & DDI & RDA \\
\hline $\mathrm{As}$ & $54.6-746.46$ & $130[55]$ \\
\hline $\mathrm{Cd}$ & $163.8-245.7$ & -- \\
\hline $\mathrm{Cu}$ & $137.28-177.84$ & $\begin{array}{c}3,000-30,000 \\
{[56]}\end{array}$ \\
\hline $\mathrm{Fe}$ & $222.3-319.8$ & $19,000[57]$ \\
\hline $\mathrm{Mn}$ & $195-273$ & -- \\
\hline $\mathrm{Se}$ & $24.96-74.88$ & $110[57]$ \\
\hline $\mathrm{Zn}$ & $249.6-390$ & $\begin{array}{c}18,000-60,000 \\
{[56]}\end{array}$ \\
\hline
\end{tabular}

Table 4: Comparision of the range of daily dietary intake (DDI) of all the elements present in fish with Recommended Dietary Allowances (RDA) in $\mu \mathrm{g} /$ day.

\section{Statistical analysis}

The Pearson correlation coefficients for all the observed heavy metals in Scomberomorus lineolatus, Lutjanus johni and Arius jella

\begin{tabular}{|c|c|c|c|}
\hline Element & $\begin{array}{c}\text { EDI ( } \mu \text { g kg BW } \text { kW }^{-1} \\
\left.\text { day }^{-1}\right)\end{array}$ & $\begin{array}{c}\text { RfD }\left(\mu g \text { kg BW }^{-1}\right. \\
\left.\text { day }^{-1}\right)\end{array}$ & HQ \\
\hline As & $0.78-10.66$ & 0.3 & $2.6-35.54$ \\
\hline $\mathrm{Cd}$ & $2.34-3.51$ & 1 & $2.34-3.51$ \\
\hline $\mathrm{Cu}$ & $1.96-2.54$ & 40 & $0.04-0.06$ \\
\hline $\mathrm{Fe}$ & $3.17-4.56$ & 700 & $0.004-0.006$ \\
\hline Mn & $2.78-3.9$ & 140 & $0.019-0.027$ \\
\hline $\mathrm{Se}$ & $0.35-1.06$ & 5 & $0.071-0.21$ \\
\hline $\mathrm{Zn}$ & $3.56-5.57$ & 300 & $0.011-0.018$ \\
\hline
\end{tabular}

Table 5: Estimated daily intake (EDI), Reference dose (RfD) and Hazard Quotient (HQ) for all the elements.

are calculated and presented in tables 6, 7 and 8 respectively. Strong correlation between two elements might indicate common uptake mechanism, or common source and lack of metabolic regulation. For Scomberomorus lineolatus, As showed significant positive correlation with $\mathrm{Cu}(0.915), \mathrm{Fe}(0.993)$ and $\mathrm{Zn} \mathrm{(0.881),} \mathrm{Cu}$ is in strong correlation with Fe (0.956) and $\mathrm{Zn} \mathrm{(0.997),} \mathrm{Fe} \mathrm{is} \mathrm{in} \mathrm{positive} \mathrm{cor-}$ relation with $\mathrm{Zn}(0.930), \mathrm{Mn}$ is in strong positive correlation with Se (0.946); the moderate negative correlation has been observed between Cd-Se (-0.710) and Cd-Mn (-0.442). For Lutjanus johni, As showed significant positive correlation with $\mathrm{Cd}(0.840)$ and Se (0.898); Cd showed strong correlation with $\mathrm{Cu}$ (0.976), Fe (0.984), Se (0.993) and Zn (0.961); Cu Showed strong positive correlation with Fe (0.999), Se (0.943) and Zn (0.998); Fe showed strong correlation with Se (0.955) and Zn (0.995); Se showed strong correlation with $\mathrm{Zn} \mathrm{(0.921);} \mathrm{no} \mathrm{significant} \mathrm{negative} \mathrm{correlation} \mathrm{is} \mathrm{observed.} \mathrm{For}$ Arius jella, significant positive correlation has been determined between As-Cd (0.982), Cu-Fe (0.997), Cu-Zn (0.977), Fe-Zn (0.958), a strong negative correlation is observed between As-Mn (-0.99) and Cd-Mn (-0.999).

\section{Conclusions}

The present work is carried out to evaluate concentration of heavy metals in various organs (muscle, liver and gills) of three commonly consumed species of fish available in Visakhapatnam coast. The results showed better understanding for the bioaccumulation of metals in selected fish species and their tissues. It is observed, in general, liver of the selected fish species accumulated highest concentrations of heavy metals while the lowest concentra- 


\begin{tabular}{|l|c|c|c|}
\hline Element & $\begin{array}{c}\text { EDI }\left(\boldsymbol{\mu g} \mathbf{~ k g ~ B W}^{-\mathbf{1}}\right. \\
\left.\mathbf{d a y}^{-1}\right)\end{array}$ & $\begin{array}{c}\text { RfD }\left(\boldsymbol{\mu g} \mathbf{~ k g ~ B W}^{-\mathbf{1}}\right. \\
\left.\mathbf{d a y}^{\mathbf{1}}\right)\end{array}$ & HQ \\
\hline As & $0.78-10.66$ & 0.3 & $2.6-35.54$ \\
\hline $\mathrm{Cd}$ & $2.34-3.51$ & 1 & $2.34-3.51$ \\
\hline $\mathrm{Cu}$ & $1.96-2.54$ & 40 & $0.04-0.06$ \\
\hline $\mathrm{Fe}$ & $3.17-4.56$ & 700 & $0.004-0.006$ \\
\hline $\mathrm{Mn}$ & $2.78-3.9$ & 140 & $0.019-0.027$ \\
\hline $\mathrm{Se}$ & $0.35-1.06$ & 5 & $0.071-0.21$ \\
\hline $\mathrm{Zn}$ & $3.56-5.57$ & 300 & $0.011-0.018$ \\
\hline
\end{tabular}

Table 5: Estimated daily intake (EDI), Reference dose (RfD) and Hazard Quotient (HQ) for all the elements.

\begin{tabular}{|l|c|c|c|c|c|c|c|}
\hline & As & Cd & Cu & Fe & Mn & Se & Zn \\
\hline As & 1 & & & & & & \\
\hline $\mathrm{Cd}$ & 0.758 & 1 & & & & & \\
\hline $\mathrm{Cu}$ & 0.915 & 0.430 & 1 & & & & \\
\hline $\mathrm{Fe}$ & 0.993 & 0.676 & 0.956 & 1 & & & \\
\hline $\mathrm{Mn}$ & 0.250 & -0.442 & 0.619 & 0.361 & 1 & & \\
\hline $\mathrm{Se}$ & -0.078 & -0.710 & 0.331 & 0.039 & 0.946 & 1 & \\
\hline $\mathrm{Zn}$ & 0.881 & 0.359 & 0.997 & 0.930 & 0.678 & 0.403 & 1 \\
\hline
\end{tabular}

Table 6: Correlation between heavy metals present in tissues of Scomberomorus lineolatus.

\begin{tabular}{|l|c|c|c|c|c|c|c|}
\hline & As & Cd & Cu & Fe & Mn & Se & Zn \\
\hline As & 1 & & & & & & \\
\hline $\mathrm{Cd}$ & 0.840 & 1 & & & & & \\
\hline $\mathrm{Cu}$ & 0.701 & 0.976 & 1 & & & & \\
\hline $\mathrm{Fe}$ & 0.728 & 0.984 & 0.999 & 1 & & & \\
\hline $\mathrm{Mn}$ & -0.146 & 0.414 & 0.603 & 0.571 & 1 & & \\
\hline $\mathrm{Se}$ & 0.898 & 0.993 & 0.943 & 0.955 & 0.304 & 1 & \\
\hline $\mathrm{Zn}$ & 0.656 & 0.961 & 0.998 & 0.995 & 0.650 & 0.921 & 1 \\
\hline
\end{tabular}

Table 7: Correlation between heavy metals present in tissues of Lutjanus johni.

\begin{tabular}{|l|c|c|c|c|c|c|c|}
\hline & As & Cd & Cu & Fe & Mn & Se & Zn \\
\hline As & 1 & & & & & & \\
\hline $\mathrm{Cd}$ & 0.982 & 1 & & & & & \\
\hline $\mathrm{Cu}$ & -0.646 & -0.490 & 1 & & & & \\
\hline $\mathrm{Fe}$ & -0.587 & -0.423 & 0.997 & 1 & & & \\
\hline $\mathrm{Mn}$ & -0.990 & -0.999 & 0.530 & 0.464 & 1 & & \\
\hline $\mathrm{Se}$ & 0.347 & 0.518 & 0.492 & 0.556 & -0.478 & 1 & \\
\hline $\mathrm{Zn}$ & -0.793 & -0.664 & 0.977 & 0.958 & 0.698 & 0.296 & 1 \\
\hline
\end{tabular}

Table 8: Correlation between heavy metals present in tissues of Arius jella.

tions are found in the muscle of species. Some trace elements show good correlation, indicating possibility of similar sources and same biogeochemical properties. Daily dietary intake (DDI), estimated daily intake (EDI) and Hazard quotient are calculated for each individual element. The hazard quotient through fish consumption is less than one in the three selected species of fish for $\mathrm{Cu}, \mathrm{Fe}, \mathrm{Mn}$ $\mathrm{Se}$, and $\mathrm{Zn}$. However, there is a matter of concern due to $\mathrm{Cd}$ and $\mathrm{As}$, as the HQ values are greater than unity, which indicated that consumption of fish caught in this region may cause consumers' health problems. Hence, it is recommended for the regular monitoring for heavy metals in this region along with the population of this region who depends upon fish catching to avoid effects of these toxic metals on human health. Further, it is important to study the speciation of As since different chemical forms of As present different levels of toxicity. Also, it is recommended that treatment of all kinds of wastewaters, sewage and agricultural wastes must be conducted before discharge into the aquatic systems.

\section{Acknowledgements}

The authors would like acknowledge DST-SERB for the financial support in the form a project.

\section{Bibliography}

1. Jusheng Zheng., et al. "Fish consumption and CHD mortality: An updated meta-analysis of seventeen cohort studies". Public Health Nutrition 15.4 (2012): 725-737.

2. Susan K Raatz., et al. "Issues of fish consumption for cardiovascular disease risk reduction". Nutrients 5.4 (2013): 1081-1097. 
3. Wei Zhao., et al. "Fish Consumption and Stroke Risk: A MetaAnalysis of Prospective Cohort Studies". Journal of Stroke and Cerebrovascular Diseases 28.3 (2019): 604-611.

4. Xiao-Feng Yu., et al. "Fish consumption and risk of gastrointestinal cancers: A meta-analysis of cohort studies". World Journal of Gastroenterology 20.41 (2014): 15398-15412.

5. Rui-Xue Huang., et al. "Fish intake and risk of liver cancer: A meta-analysis". PLoS One 10.1 (2015): e0096102.

6. Gengxi Jiang., et al. "Poultry and fish intake and risk of esophageal cancer: A meta-analysis of observational studies". AsiaPacific Journal of Clinical Oncology 12.1 (2016): e82-91.

7. Shengjun $\mathrm{Wu}$., et al. "Fish consumption and colorectal cancer risk in humans: A systematic review and meta-analysis". American Journal of Medicine 125.6 (2012): 551-559. e5.

8. Jian Song., et al. "Fish consumption and lung cancer risk: Systematic review and meta-analysis". Nutrition and Cancer 66.4 (2014): 539-549.

9. Ya-Zhu Wang., et al. "Fish consumption and risk of myeloma: a meta-analysis of epidemiological studies". Cancer Causes Control 26.9 (2015): 1307-1314.

10. Abdulkadir Bayır., et al. "Fatty acid composition in some selected marine fish species living in Turkish waters". Journal of the Science of Food and Agriculture 86.1 (2006): 163-168.

11. Gunveen Kaur., et al. "Docosapentaenoic acid (22:5n-3): A review of its biological effects". Progress in Lipid Research 50.1 (2011): 28-34.

12. H R Knapp., et al. "In vivo indexes of platelet and vascular function during fish-oil administration in patients with atherosclerosis". The New England Journal of Medicine 314.15 (1986): 937-942.

13. Quan Zhou., et al. "EPA+DHA, but not ALA, Improved Lipids and Inflammation Status in Hypercholesterolemic Adults: A Randomized, Double-Blind, Placebo-Controlled Trial". Molecular Nutrition and Food Research 63.10 (2019): e1801157.

14. Jie Peng., et al. "Maternal Eicosapentaenoic Acid Feeding Decreases Placental Lipid Deposition and Improves the Homeo- stasis of Oxidative Stress Through a Sirtuin-1 (SIRT1) Independent Manner". Molecular Nutrition and Food Research 63.21 (2019): e1900343.

15. Mandana Pahlavani., et al. "Eicosapentaenoic Acid Reduces Adiposity, Glucose Intolerance and Increases Oxygen Consumption Independently of Uncoupling Protein 1". Molecular Nutrition and Food Research 63.7 (2019): e1800821.

16. Miao-Miao Zhou., et al. "Comparative Study of Different Polar Groups of EPA-Enriched Phospholipids on Ameliorating Memory Loss and Cognitive Deficiency in Aged SAMP8 Mice". Molecular Nutrition and Food Research 62.7 (2018): e1700637.

17. Mohammad MN Authman., et al. "Use of Fish as Bio-indicator of the Effects of Heavy Metals Pollution". Aquaculture Research and Development Journal 6.4 (2015): 328.

18. Chiarelli R and Roccheri M. "Marine Invertebrates as Bioindicators of Heavy Metal Pollution". Open Journal of Metal 4 (2014): 93-106.

19. Nahida B Al-Majed and Martin R Preston. "An Assessment of the Total and Methyl Mercury Content of Zooplankton and Fish Tissue Collected from Kuwait Territorial Waters". Marine Pollution Bulletin 40.4 (2000): 298-307.

20. S Siavash Saei-Dehkordi., et al. "Arsenic and mercury in commercially valuable fish species from the Persian Gulf: Influence of season and habitat". Food and Chemical Toxicology 48.10 (2010): 2945-2950.

21. A H al-Hashimi and M A al-Zorba. "Mercury in some commercial fish from Kuwait: a pilot study". Science of the Total Environment 106.1-2 (1991): 71-82.

22. M H Al-Yousuf., et al. "Trace metals in liver, skin and muscle of Lethrinus lentjan fish species in relation to body length and sex". Science of the Total Environment 256.2-3 (2000): 87-94.

23. Mohammad Seddiq Mortazavi and Salim Sharifian. "Metal concentrations in two commercial fish from Persian Gulf, in relation to body length and sex". Bulletin of Environmental Contamination and Toxicology 89.3 (2012): 450-454.

24. N A Barak and C F Mason. "Mercury, cadmium and lead in eels and roach: The effects of size, season and locality on metal con- 
centrations in flesh and liver". Science of the Total Environment 92 (1990): 249-256.

25. Saptadipa Paul., et al. "Health risk assessment of Macro, Traceelements and heavy metal in various Indian Antidiabetic Polyherbal formulations". Environmental Science and Pollution Research (2021).

26. Svobodová Z., et al. "Water quality and fish health". EIFAC Technical Paper. No. 54. Rome, FAO (1993): 59.

27. C M Liao., et al. "Organ-specific toxicokinetics and dose-response of arsenic in tilapia Oreochromis mossambicus". Archives of Environmental Contamination and Toxicology 47.4 (2004): 502-510.

28. D G Sfakianakis., et al. "Effect of heavy metals on fish larvae deformities: A review”. Environmental Research 137 (2015): 246255.

29. Judit Kalman., et al. "Comparative toxicity of cadmium in the commercial fish species Sparus aurata and Solea senegalensis". Ecotoxicology and Environmental Safety 73.3 (2010): 306-311.

30. Chung-Min Liao., et al. "Assessing the impact of waterborne and dietborne cadmium toxicity on susceptibility risk for rainbow trout". Science of The Total Environment 409.3 (2011): 503-513.

31. Lars Järup. "Hazards of heavy metal contamination". British Medical Bulletin 68 (2003): 167-182.

32. Faroon O., et al. "Toxicological Profile for Cadmium". Atlanta (GA): Agency for Toxic Substances and Disease Registry (US) (2012).

33. Sandra Mariza Monteiro., et al. "Copper toxicity in gills of the teleost fish, Oreochromis niloticus: Effects in apoptosis induction and cell proliferation". Aquatic Toxicology 94.3 (2009): 219-228.

34. Pedro P Hernández., et al. "Sub-lethal concentrations of waterborne copper are toxic to lateral line neuromasts in zebrafish (Danio rerio)". Heart Research 213.1-2 (2006): 1-10.

35. Mohsen Abdel-Tawwab., et al. "Growth performance and physiological response of African catfish, Clariasgariepinus (B.) fed organic selenium prior to the exposure to environmental copper toxicity". Aquaculture 272.1-4 (2007): 335-345.

36. A K Shrivastava. "A review on Copper Pollution and its Removal from Water Bodies by Pollution Control Technologies". Indian Journal of Environmental Protection 29.6 (2009): 552-560.

37. Jezierska B and Witeska M. "THE METAL UPTAKE AND ACCUMULATION IN FISH LIVING IN POLLUTED WATERS”. In: Twardowska I., Allen H.E., Häggblom M.M., Stefaniak S. (eds) Soil and Water Pollution Monitoring, Protection and Remediation. NATO Science Series. Springer, Dordrecht 69 (2006).

38. C DECKER., et al. "Acute toxicity of iron and aluminum to brook trout" (1974).

39. Eurika Grobler-Van Heerden., et al. "Bioconcentration of atrazine, zinc and iron in the blood of Tilapia sparrmanii (cichlidae)". Comparative Biochemistry and Physiology Part C: Comparative Pharmacology 100.3 (1991): 629-633.

40. Wael A Omar., et al. "Integrating multiple fish biomarkers and risk assessment as indicators of metal pollution along the Red Sea coast of Hodeida, Yemen Republic". Ecotoxicology and Environmental Safety 110 (2014): 221-231.

41. D J B Dalzell and N A A Macfarlane. "The toxicity of iron to brown trout and effects on the gills: a comparison of two grades of iron sulphate". Journal of Fish Biology 55.2 (1999): 301-315.

42. Yanbo Wang., et al. "Effect of different selenium source on growth performances, glutathione peroxidase activities, muscle composition and selenium concentration of allogynogenetic crucian carp (Carassius auratus gibelio)". Animal Feed Science and Technology 134.3-4 (2007): 243-251.

43. Hossam H H Abbas and Mohammad M N Authman. "Effects of Accumulated Selenium on Some Physiological Parameters Oxidative Stress Indicators in Tilapia Fish (Oreochromis spp.)". American-Eurasian Journal of Agricultural and Environmental Sciences 5.2 (2009): 219-225.

44. Monteiro DA., et al. "The effects of selenium on oxidative stress biomarkers in the freshwater characid fish matrinxã, Brycon cephalus (Günther, 1869) exposed to organophosphate insecticide Folisuper 600 BR (methyl parathion)". Comparative Bio- 
chemistry and Physiology Part C: Comparative Pharmacology 149.1 (2009): 40-49.

45. Li H., et al. "Elemental selenium particles at nano-size (NanoSe) are more toxic to Medaka (Oryzias latipes) as a consequence of hyper-accumulation of selenium: a comparison with sodium selenite". Aquatic Toxicology 89.4 (2008): 251-256.

46. Chien LC., et al. "Pharmacokinetic model of daily selenium intake from contaminated seafood in Taiwan". Science of the Total Environment 311.1-3 (2003): 57-64.

47. A Dennis Lemly. "Symptoms and implications of selenium toxicity in fish: The Belews Lake case example". Aquatic Toxicology 57.1-2 (2002): 39-49.

48. Miller LL., et al. "Effects of acute and subchronic exposures to waterborne selenite on the physiological stress response and oxidative stress indicators in juvenile rainbow trout". Aquatic Toxicology 83.4 (2007): 263-271.

49. U Celik and J Oehlenschläger. "Determination of zinc and copper in fish samples collected from Northeast Atlantic by DPSAV". Food Chemistry 87.3 (2004): 343-347.

50. J Sires. "A Review of Potential Zinc and Copper Pollution Sources in the Kenai River Watershed" (2017).

51. S Niyogi and C M Wood. "Interaction between dietary calcium supplementation and chronic waterborne zinc exposure in juvenile rainbow trout, Oncorhynchus mykiss". Comparative Biochemistry and Physiology Part C: Toxicology 143.1 (2006): 94-102.

52. Needham S and Funge-Smith S J. "The consumption of fish and fish products in the Asia-Pacific region based on household surveys". FAO Regional Office for Asia and the Pacific, Bangkok, Thailand. RAP Publication 2015/12 (2014): 87.

53. Onsanit S., et al. "Trace elements in two marine fish cultured in fish cages in Fujian province, China". Environmental Pollution 158.5 (2010): 1334-1342.

54. Zhang W., et al. "Large-scale spatial and interspecies differences in trace elements and stable isotopes in marine wild fish from Chinese waters". Journal of Hazardous Material 215-216 (2012): 65-74.
55. JECFA. Evaluation of certain food additives and contaminants. Thirty-third report of the joint FAO/WHO Expert Committee on Food Additives (WHO technical report series, no. 776), World Health Organization, Geneva (1989).

56. JECFA. Evaluation of certain food additives and contaminants. Twenty-sixth report of the joint FAO/WHO Expert Committee on Food Additives (WHO technical report series, no. 683), World Health Organization, Geneva (1982).

57. IAEA. IAEA-TECDOC-1005. Compilation of anatomical, physiological and metabolic characteristics for a Reference Asian man. Data summary and conclusions (1998).

\section{Volume 5 Issue 10 October 2021 \\ (C) All rights are reserved by Daisy Joseph., et al.}

